\title{
Infrared Thermography to Evaluate Heat Tolerance in Different Genetic Groups of Lambs
}

\section{Concepta McManus ${ }^{1,2}$, Eliandra Bianchini ${ }^{1, \dagger}$, Tiago do Prado Paim ${ }^{3, \dagger, *}$, Flavia Gontijo de Lima ${ }^{4, \dagger}$, José Braccini Neto ${ }^{2, \dagger}$, Marlos Castanheira ${ }^{4, \dagger}$, Geisa Isilda Ferreira Esteves ${ }^{1, \dagger}$, Caio Cesar Cardoso ${ }^{1, \dagger}$ and Vanessa Calderaro Dalcin ${ }^{2, \dagger}$}

1 Faculdade de Agronomia e Medicina Veterinária, Universidade de Brasília, Brasília 70910-900, DF, Brasil; E-Mails: concepta.mcmanus@ufrgs.br (C.M.); eliandrabianchini@gmail.com (E.B.); isildinha@gmail.com (G.I.F.E.); cajug29@gmail.com (C.C.C.)

2 Departamento de Zootecnia, Universidade Federal do Rio Grande do Sul, Porto Alegre 91540-000, Brasil; E-Mails: jose.braccini@ufrgs.br (J.B.N.); vanessacdalcin@yahoo.com.br (V.C.D.)

3 Instituto Federal de Educação, Ciência e Tecnologia Goiano-Campus Iporá, Iporá 76200-000, Brasil

4 Escola de Veterinária, Universidade Federal de Goiás, Goiânia, Goiás Paulo 74690-900, Brasil; E-Mails: flaviamedvet@yahoo.com.br(F.G.L.); castanheira_m@hotmail.com (M.C.)

$\dagger$ These authors contributed equally to this work.

* Author to whom correspondence should be addressed; E-Mail: pradopaim@hotmail.com; Tel./Fax: +55-61-9966-7886.

Academic Editor: Vittorio M.N. Passaro

Received: 6 March 2015 / Accepted: 13 July 2015 / Published: 16 July 2015

Abstract: Heat stress is considered a limiting factor for sheep production. We used
information from physiological characteristics linked to heat tolerance to determine
whether infrared thermography temperatures were able to separate groups of animals and
determine the most important variables in this differentiation. Forty-eight four-month-old
male lambs from eight genetic groups were used. Physiological (rectal temperature-RT,
heart rate-HR, respiratory rate-RR) and blood traits, infrared thermography temperatures,
heat tolerance indices, body measurements, weight and carcass traits were measured.
Statistical analyses included variance, correlations, factor, discrimination and regression.
Observing the correlations between physiological characteristics (RT, RR and HR) with
temperatures measured by infrared thermography, regions for further studies should
include the mean temperature of flank, nose and rump. Results show that there are strong 
relationships between thermograph measurements and RR, RT and HR in lambs, which are suggested to be directly correlated with heat tolerance capacity of the different genetic groups evaluated in this study. The assessment of body surface temperature measured by the thermograph could be used as a noninvasive tool to assess heat tolerance of the animals.

Keywords: adaptation; naturalized breeds; genetic resources; temperature; tropical

\section{Introduction}

Heat stress is a limiting factor for sheep production in tropical or warm regions. It has been shown that it is necessary to select animals adapted to harsh environments, often outside their physiological comfort zone, for production purposes [1]. Recently, several terminal sire ram breeds have been introduced into tropical areas of Brazil for use in crossbreeding systems. The environmental origin of the breeds is frequently different from those where they are expected to produce and reproduce [2]. Therefore, crossing local breeds may produce a non-optimal adaptation to the local environmental conditions, and finally contribute to important economic losses.

Breed choice for sheep production in the tropics should take into account adaptation to the environment and the effects of climate on the physiological parameters and performance of animals [3]. In recent years, with climate changes, research on animal welfare has intensified in an attempt to minimize economic losses due to the effects of climate on animal production in the tropics [4]. Animal welfare is a demand for any breeding system that wants to be ethically defensible and socially acceptable [5].

Animal breeding must respond quickly to climate change under predicted acceleration of global warming [6]. Global warming will anticipate changes in the vegetation of tropical regions and in some places the pasture area may decrease by up to $50 \%$ [7]. The effects of climate on animal production are therefore of interest to agricultural and public policy makers [8].

Sheep are animals that are well adapted to diverse ecosystems. Temperature and relative humidity are factors that can influence the rearing of these animals. At high temperatures and high radiation, they have difficulty in losing heat and, thereby, regulation of their internal temperatures [1]. For ruminants raised in tropical conditions, in general, the thermolysis mechanism is considered more effective than evaporation since the ambient air temperature tends to be close to skin surface temperature, neutralizing heat exchange by conduction and convection [9]. Several physiological characteristics have been used to evaluate the suitability of the animal in adverse climates [2].

The aim of this study was to evaluate the use of information from physiological characteristics related to heat tolerance, blood parameters, temperatures measured with infrared thermography, morphometric measurements and carcass traits in lambs of different genetic groups. Moreover, we aimed to determine the usefulness of infrared thermography to evaluate heat tolerance and the usefulness of the traits measured to separate genetic groups and determine the most important variables in the differentiation of these groups for heat tolerance. 


\section{Experimental Section}

Forty eight four-month-old male lambs from eight genetic groups were used: $50 \%$ East Friesian $\times 50 \%$ Santa Inês (EFSI); 50\% Primera $\times 50 \%$ Santa Inês (PRSI); $87.5 \%$ Poll Dorset $\times 12.5 \%$ Santa Inês (87PDSI); $100 \%$ Santa Inês (SI); 50\% Dorper $\times 50 \%$ Poll Dorset (DOPD); $50 \%$ Poll Dorset $\times 50 \%$ Santa Inês (PDSI); 50\% White Dorper $\times 50 \%$ Poll Dorset (WDPD); 75\% Poll Dorset $\times 25 \%$ Santa Inês (75PDSI).

The animals were fed Tifton 85 (Cynodon spp.) hay ad libitum and $300 \mathrm{~g} /$ day of a concentrate based on corn, soybean and minerals. During the experimental period, air temperature (AT) and relative humidity (RH), black globe temperature in the sun (BGTsun) and shade (BGTsd) and wind speed (WS) were obtained using an environmental monitoring station.

Rectal temperature $(\mathrm{RT})$, respiratory rate $(\mathrm{RR})$ and heart rate $(\mathrm{HR})$ were measured on two occasions: at 6:30 a.m. and 12:00 p.m. with six repetitions. Between the two collections, the animals were kept in open sunlight. RT was measured using a digital clinical thermometer inserted near the rectal wall of animal, at a depth of approximately $3.5 \mathrm{~cm}$. RR and HR were measured using a stethoscope.

The indices of heat tolerance calculated included:

Temperature and humidity index $(\mathrm{THI}): \mathrm{THI}=\mathrm{Tdb}{ }^{\circ} \mathrm{C}-\left\{(0.31-0.31 \mathrm{RH})\left(\mathrm{Tdb}{ }^{\circ} \mathrm{C}-14.4\right)\right\}$

where: Tdb: dry bulb temperature (air temperature) and $\mathrm{RH}$ : relative air humidity (\%);

$$
\text { Rauschenbach-Yerokhin [10]: ITC }=1.0 \mathrm{AT}-20 \mathrm{~d}+60
$$

where: $\mathrm{AT}=$ air temperature and $\mathrm{d}=$ difference between 6 a.m. and 12 p.m. rectal temperatures and a value closer to 100 indicates a better adapted animal;

$$
\text { Ibéria or Rhoad test: CTC }=100-[18(\mathrm{RT}-39.1)]
$$

where $\mathrm{CTC}=$ heat tolerance coefficient; $100=$ maximum efficiency in maintaining body temperature below $39.1{ }^{\circ} \mathrm{C} ; 18=$ constant; RT = mean final rectal temperature; $39.1{ }^{\circ} \mathrm{C}=$ normal mean rectal temperature for sheep [11]. Value closer to 100 indicates a better adapted animal;

$$
\text { Benezra test: } \mathrm{CA}=\mathrm{RT} / 39.1+\mathrm{RR} / 27
$$

where: $\mathrm{CA}=$ adaptability coefficient; $\mathrm{RT}=$ rectal temperature in ${ }^{\circ} \mathrm{C} ; \mathrm{RR}=$ respiratory rate per minute; $39.1{ }^{\circ} \mathrm{C}=$ normal mean rectal temperature for sheep; $27=$ normal mean respiratory rate for sheep [11]. Value close to two means animals that are better adapted;

$$
\text { Adapted from Baccari Jr. [12]: ICTI }=10-(\mathrm{RT} 2-\mathrm{RT} 1)
$$

where: ICTI $=$ Index of capacity of tolerance to insolation; $10=$ maximum efficiency in maintaining body temperature; RT2 = mean body temperature at $12 \mathrm{~h}$; and RT1 = mean body temperature at $6.5 \mathrm{~h}$. Value closer to 10 indicates better adapted animals.

Hematologic parameters in both periods (morning and afternoon) were determined from blood samples using a Mindray BC 2800 vet apparatus and the microhematocrit technique was used for determination of plasma fibrinogen. Absolute red blood cell (RBC) indices were calculated: mean corpuscular volume (MCV), red cell distribution width (RDW), mean corpuscular hemoglobin (MCH) and mean corpuscular hemoglobin concentration (MCHC). 
Surface temperatures were measured with infrared thermography (FLIR i-Series ${ }^{\circledR}$ system) and analyzed using QuickReport ${ }^{\circledR}$ software. Temperatures were measured in the regions of the nose, head (a point next to brain location), neck, axilla, stifle and croup of animals, as well as a mean temperature forflank, following the same temperature points measured by Paim et al. [13].

Body measurements, such as wither height (WH); heart girth (HG); body length (BL); back length (LB) and skin thickness (ST), were measured. Animals were then slaughtered and cold carcass weight (CW) as well as commercial cuts including neck, belly, shoulder, shank, rib and back were measured according to Silva Sobrinho [14]. Percentages of cuts were calculated dividing double the cut weight by $\mathrm{CW}$.

Data were analyzed using the SAS ${ }^{\circledR}$ software using MIXED procedure for analysis of variance with an unstructured covariance matrix for the significant variables selected by the BIC criterion. Stepwise multivariate regression (REG) was used to test the use of infrared thermography in determining changes in physiological variables. Data was separated into physiological traits with indices and carcass traits with body size measurements, and these were analyzed separately for the morning and afternoon. A factor analysis (FACTOR) was used to examine the relationship between the variables. Clusters (FASTCLUS) were formed and a discriminant analysis (DISCRIM) was used to predict the traits that differentiated between genetic groups. Normality was tested using the Univariate procedure. Non-normal characteristics were transformed: percentages and proportions by arcsine; counts by square root and others using Tukey's Ladder of Powers.

\section{Results}

The temperature and humidity index (THI) in the morning classified the environment as being moderately stressful (22.69). In the afternoon, the animals were subjected to extremely severe stress (ranging from 26.69 to 28.78). Based on the scale proposed by Silanikove [15], 23.73\% of the sheep on this experiment were under high stress and $51.75 \%$ under very high stress in the afternoon, i.e., the animals were using RR as a means of heat dissipation to maintain their homeothermy (Table 1). The maximum RR in sheep during the experiment was $192 \mathrm{mov} \cdot \mathrm{min}^{-1}$.

Table 1. Scaling of respiratory rate (RR) of sheep in this experiment, according to the period of the day.

\begin{tabular}{cccc}
\hline RR for Sheep & Stress Level & Morning \% Animals & Afternoon \% Animals \\
\hline$<40 \mathrm{mov} \cdot \mathrm{min}^{-1}$ & Absence & 84.72 & 0.72 \\
$40-60 \mathrm{mov} \cdot \mathrm{min}^{-1}$ & Low & 11.81 & 14.36 \\
$61-80 \mathrm{mov} \cdot \mathrm{min}^{-1}$ & Medium-High & 2.08 & 10.13 \\
$81-120 \mathrm{mov} \cdot \mathrm{min}^{-1}$ & High & 0.69 & 23.04 \\
$121-192 \mathrm{mov} \cdot \mathrm{min}^{-1}$ & Very High & - & 51.75 \\
$>193 \mathrm{mov} \cdot \mathrm{min}^{-1}$ & Severe & - & - \\
\hline
\end{tabular}

* Adapted from Silanikove [15].

The RT in the afternoon $\left(39.95^{\circ} \mathrm{C}\right)$ was higher $(p<0.0001)$ than in the morning $\left(38.89^{\circ} \mathrm{C}\right)$. Table 2 shows that the PRSI genetic group had the lowest RT temperature $\left(39.43{ }^{\circ} \mathrm{C}\right)$ in the afternoon, differing from the other genetic groups. In the morning, the SI had the lowest RT $\left(38.27^{\circ} \mathrm{C}\right)$ while 
WDPD showed higher RR in the afternoon than EFSI, and EFSI showed higher RR than 75PDSI, PDSI, PRSI and SI in the morning. HR in the morning also showed EFSI with higher values than 75PDSI, PDSI, SI and WDPD.

Table 2. Means of the genetic groups physiological characteristics (HR, RR and RT)

\begin{tabular}{ccccccc}
\hline \multirow{2}{*}{ Genetic Group } & \multicolumn{2}{c}{ HR } & \multicolumn{2}{c}{ RR } & \multicolumn{2}{c}{ RT } \\
\cline { 2 - 7 } & $\mathrm{M}$ & $\mathrm{A}$ & $\mathrm{M}$ & $\mathrm{A}$ & $\mathrm{M}$ & $\mathrm{A}$ \\
\hline 75PDSI & $66.66^{\mathrm{dc}}$ & 72.44 & $27.77^{\mathrm{b}}$ & $122.44^{\mathrm{ab}}$ & $38.81^{\mathrm{b}}$ & $39.98^{\mathrm{b}}$ \\
87PDSI & $80.22^{\mathrm{ab}}$ & 76.50 & $33.77^{\mathrm{ab}}$ & $119.0^{\mathrm{ab}}$ & $39.32^{\mathrm{a}}$ & $40.08^{\mathrm{ab}}$ \\
DOPD & $73.77^{\mathrm{abc}}$ & 79.33 & $32.88^{\mathrm{ab}}$ & $124.89^{\mathrm{ab}}$ & $39.30^{\mathrm{a}}$ & $40.36^{\mathrm{a}}$ \\
EFSI & $81.55^{\mathrm{a}}$ & 79.55 & $39.77^{\mathrm{a}}$ & $93.78^{\mathrm{b}}$ & $38.77^{\mathrm{b}}$ & $39.80^{\mathrm{b}}$ \\
PDSI & $62.66^{\mathrm{d}}$ & 74.66 & $28.22^{\mathrm{b}}$ & $134.22^{\mathrm{ab}}$ & $38.86^{\mathrm{b}}$ & $39.94^{\mathrm{b}}$ \\
PRSI & $75.33^{\mathrm{abc}}$ & 74.85 & $25.77^{\mathrm{b}}$ & $100.50^{\mathrm{ab}}$ & $38.72^{\mathrm{b}}$ & $39.43^{\mathrm{c}}$ \\
SI & $70.00^{\mathrm{bcd}}$ & 78.82 & $27.33^{\mathrm{b}}$ & $112.24^{\mathrm{ab}}$ & $38.27^{\mathrm{c}}$ & $39.89^{\mathrm{b}}$ \\
WDPD & $65.77^{\mathrm{dc}}$ & 76.66 & $33.55^{\mathrm{ab}}$ & $138.22^{\mathrm{a}}$ & $39.05^{\mathrm{ab}}$ & $40.07^{\mathrm{ab}}$ \\
Mean & $71.99^{\mathrm{a}}$ & $76.60^{\mathrm{b}}$ & $31.52^{\mathrm{a}}$ & $118.16^{\mathrm{b}}$ & $38.88^{\mathrm{a}}$ & $39.94^{\mathrm{b}}$ \\
\hline
\end{tabular}

Means followed by different letters by column are significantly different using SNK test $(p<0.05)$. HR-heart rate; RR-respiratory rate; RT-rectal temperature; M-morning; A-afternoon. PD: Poll Dorset; PR: Primera; EF: East Friesian; SI:Santa Inês; WD: White Dorper; DO: Dorper.

The numbers of erythrocytes were higher in SI $\left(13.14 \times 10^{6} \mathrm{~mm}^{-3}\right)$ and DOPD (12.87) than WDPD (11.24) and 75PDSI (11.22). The same pattern was seen in hemoglobin concentration. The SI had higher MCV (31.50) than PRSI (27.33), WDPD (26.76) and 75PDSI (26.75). The genetic group DOPD had the highest MCHC and EFSI genetic group showed higher RDW. The WDPD had higher fibrinogen (477.78) than EFSI (211.11).

AT, RH, WS, BGTsun and BGTsd climatic variables affected $(p<0.05)$ the thermography measurements, which may infer that environmental conditions influenced the increase of the animal's body temperature. In general, the EFSI genetic group obtained the highest thermographic measures, and the lowest were observed in the 87PDSI genetic group (Table 3). The nose measurements did not differ between genetic groups.

Table 3. Mean values of the temperatures obtained with the thermograph in their respective regions, according to the sheep genetic group.

\begin{tabular}{cccccccc}
\hline Genetic Group & ${\text { Rump }\left({ }^{\circ} \mathbf{C}\right)}$ & Head $\left({ }^{\circ} \mathbf{C}\right)$ & Axilla $\left({ }^{\circ} \mathbf{C}\right)$ & Neck $\left({ }^{\circ} \mathbf{C}\right)$ & Groin $\left({ }^{\circ} \mathbf{C}\right)$ & Nose $\left({ }^{\circ} \mathbf{C}\right)$ & Flank $\left({ }^{\circ} \mathbf{C}\right)$ \\
\hline $75 P D S I$ & $33.84^{\mathrm{a}}$ & $33.61^{\mathrm{abc}}$ & $34.08^{\mathrm{ab}}$ & $32.71^{\mathrm{b}}$ & $33.68^{\mathrm{bc}}$ & 33.10 & $33.62^{\mathrm{a}}$ \\
87PDSI & $31.95^{\mathrm{b}}$ & $32.80^{\mathrm{c}}$ & $33.10^{\mathrm{bc}}$ & $31.29^{\mathrm{c}}$ & $32.99^{\mathrm{dc}}$ & 32.86 & $32.00^{\mathrm{b}}$ \\
DOPD & $33.23^{\mathrm{ab}}$ & $34.26^{\mathrm{ab}}$ & $35.01^{\mathrm{a}}$ & $32.95^{\mathrm{b}}$ & $34.53^{\mathrm{ab}}$ & 33.19 & $33.25^{\mathrm{a}}$ \\
EFSI & $33.01^{\mathrm{ab}}$ & $34.49^{\mathrm{a}}$ & $35.12^{\mathrm{a}}$ & $34.26^{\mathrm{a}}$ & $35.29^{\mathrm{a}}$ & 33.52 & $34.02^{\mathrm{a}}$ \\
PDSI & $34.11^{\mathrm{a}}$ & $34.01^{\mathrm{ab}}$ & $34.94^{\mathrm{a}}$ & $33.14^{\mathrm{b}}$ & $35.11^{\mathrm{ab}}$ & 32.78 & $34.04^{\mathrm{a}}$ \\
PRSI & $32.68^{\mathrm{ab}}$ & $33.80^{\mathrm{ab}}$ & $34.39^{\mathrm{a}}$ & $33.67^{\mathrm{ab}}$ & $34.97^{\mathrm{ab}}$ & 32.69 & $33.39^{\mathrm{a}}$ \\
SI & $33.69^{\mathrm{a}}$ & $33.63^{\mathrm{abc}}$ & $35.16^{\mathrm{a}}$ & $34.64^{\mathrm{a}}$ & $35.85^{\mathrm{a}}$ & 32.68 & $34.42^{\mathrm{a}}$ \\
WDPD & $32.66^{\mathrm{ab}}$ & $33.39^{\mathrm{bc}}$ & $32.64^{\mathrm{c}}$ & $31.44^{\mathrm{c}}$ & $32.03^{\mathrm{d}}$ & 32.60 & $32.15^{\mathrm{b}}$ \\
\hline
\end{tabular}

Means followed by different letters by column are significantly different using SNK test $(p<0.05)$. PD: Poll Dorset; PR: Primera; EF: East Friesian; SI: Santa Inês; WD: White Dorper; DO: Dorper. 
No statistical difference was observed comparing genetic groups using the Benezra test (Table 4). The SI had the lowest index for Baccari Jr. (8.32) and Rauschenbach-Yerokhin (54.48), which indicate poorest heat tolerance.

Table 4. Mean values of the adaptability tests for genetic groups of sheep in Central-West Brazil.

\begin{tabular}{ccccc}
\hline Genetic Group & Rauschenbach-Yerokhin & Ibéria & Benezra & Baccari Jr. Adapted \\
\hline 75 PDSI & $64.58^{\mathrm{a}}$ & $88.74^{\mathrm{ab}}$ & 3.75 & $8.82^{\mathrm{a}}$ \\
87PDSI & $73.28^{\mathrm{a}}$ & $88.30^{\mathrm{ab}}$ & 3.70 & $9.26^{\mathrm{a}}$ \\
DOPD & $66.78^{\mathrm{a}}$ & $84.30^{\mathrm{b}}$ & 3.89 & $8.93^{\mathrm{a}}$ \\
EFSI & $66.51^{\mathrm{a}}$ & $89.17^{\mathrm{ab}}$ & 3.42 & $8.92^{\mathrm{a}}$ \\
PDSI & $66.33^{\mathrm{a}}$ & $89.35^{\mathrm{ab}}$ & 3.96 & $8.91^{\mathrm{a}}$ \\
PDWD & $67.67^{\mathrm{a}}$ & $88.35^{\mathrm{ab}}$ & 4.15 & $8.98^{\mathrm{a}}$ \\
PRSI & $72.70^{\mathrm{a}}$ & $92.40^{\mathrm{a}}$ & 3.22 & $9.23^{\mathrm{a}}$ \\
SI & $54.48^{\mathrm{b}}$ & $83.86^{\mathrm{b}}$ & 3.50 & $8.32^{\mathrm{b}}$ \\
\hline
\end{tabular}

Means followed by different letters by column differ using SNK test $(p<0.05)$. PD: Poll Dorset; PR:

Primera; EF: East Friesian; SI:Santa Inês; WD: White Dorper; DO: Dorper.

The predictive regression equations (Table 5) show that flank, nose, rump and neck temperatures are the best predictors of physiological responses to heat. The inclusion of air temperature or humidity in the equation increased $\mathrm{R}^{2}$ by approximately $1 \%$ while air temperatures or humidity alone gave predictive equations approximately $20 \%$ lower than those shown here.

Table 5. Multiple regressions for rates of heat tolerance and physiological variables using infrared thermography.

\begin{tabular}{|c|c|c|}
\hline Variables & Multivariate Regression Equation & $\mathbf{R}^{2}$ \\
\hline Ibéria & $156.43-3.24$ nose $* * *+2.05$ neck $* * *-0.02$ rump $^{2} * * *$ & 0.50 \\
\hline Benezra & $49.95-2.58$ nose $^{* *}+0.04 \operatorname{nose}^{2 * *}+0.02 \operatorname{rump}^{2 * *}$ & 0.50 \\
\hline RY & $873.47-1.21$ flank $* *-49.40$ nose $* *+0.75$ nose $^{2 * *}$ & 0.30 \\
\hline Baccari & $-30.42-0.07$ flank $* *+2.56$ nose $* * *-0.03$ nose $^{2 * * *}$ & 0.33 \\
\hline $\mathrm{RR}$ & $-122.14+0.102$ nose $^{2} *+0.071$ rump $^{2 *}$ & 0.50 \\
\hline HR & $91.46+0.03 \operatorname{nose}^{2 * *}$ & 0.05 \\
\hline RT & $35.96+0.18$ nose $* * *-0.11$ neck $* * *+0.001$ rump $^{2} * * *$ & 0.50 \\
\hline
\end{tabular}

RY: Rauschenbach - Yerokhin; RR: respiratory rate; HR: heart rate; RR: rectal temperature; $* * * p<0.0001$; $* * p<0.001 ; * p<0.05$.

The correlations between the temperatures measured by infrared thermography and RR were high and positive for the flank $(r=0.72)$, rump (0.75) and nose (0.68). Rectal temperature was correlated positively with thermal image temperatures for flank $(\mathrm{r}=0.54)$, head $(0.58)$, nose $(0.72)$ and rump (0.62). RR and RT had a correlation of 0.70 . The infrared temperatures had high and positive correlations with Benezra: flank $(\mathrm{r}=0.72)$, head $(0.66)$, nose $(0.68)$, neck (0.63) and rump (0.75). The Iberia test showed correlations with nose $(\mathrm{r}=-0.72)$ and rump $(-0.62)$. The flank temperature had medium correlations RY (0.33) and Baccari (-0.39) tests.

The infrared temperatures had significant correlations with environmental factors. The AT had high and positive correlations with all surface temperatures $(0.54<\mathrm{r}<0.82)$. The BGT under sun and shade 
had high and positive correlations with all surface temperatures $(0.58<\mathrm{r}<0.88)$. In both, the axilla had the lowest correlation and the rump and the flank had the highest. The regression equations (Table 6 and Figure 1) show the relation between environmental factors, such as air temperature (AT), air relative humidity (RH), wind speed (WS) and BGT under sun (BGTsun) and shade (BGTsd), and the infrared temperatures. The regressions showed the BGTsd explaining a high proportion of variation in infrared temperatures, mainly the flank and rump points (Figure 1).

Table 6. Multiple regressions for infrared thermography data using environmental factors.

\begin{tabular}{ccc}
\hline Variables & Multivariate Regression Equation & $\mathbf{R}^{\mathbf{2}}$ \\
\hline Neck & $24.96+0.23 \mathrm{BGTsd} * *$ & 0.59 \\
Groin & $27.81+0.187 \mathrm{BGTsd} * * *$ & 0.39 \\
Axilla & $29.31+0.139 \mathrm{BGTsd} * * *$ & 0.34 \\
Head & $58.60+1.14 \mathrm{WS} *+0.172 \mathrm{BGTsd} * * *-2.249 \mathrm{AT}^{*}+0.04 \mathrm{AT}^{2} *$ & 0.33 \\
Nose & $27.79+1.40 \mathrm{WS} * *+0.144 \mathrm{BGTsd} * *$ & 0.59 \\
\hline
\end{tabular}

BGTshade: black globe temperature under shdade; WS: wind speed; AT: air temperature; ${ }^{* *} p<0.0001$; ** $p<0.001 ; * p<0.05$;

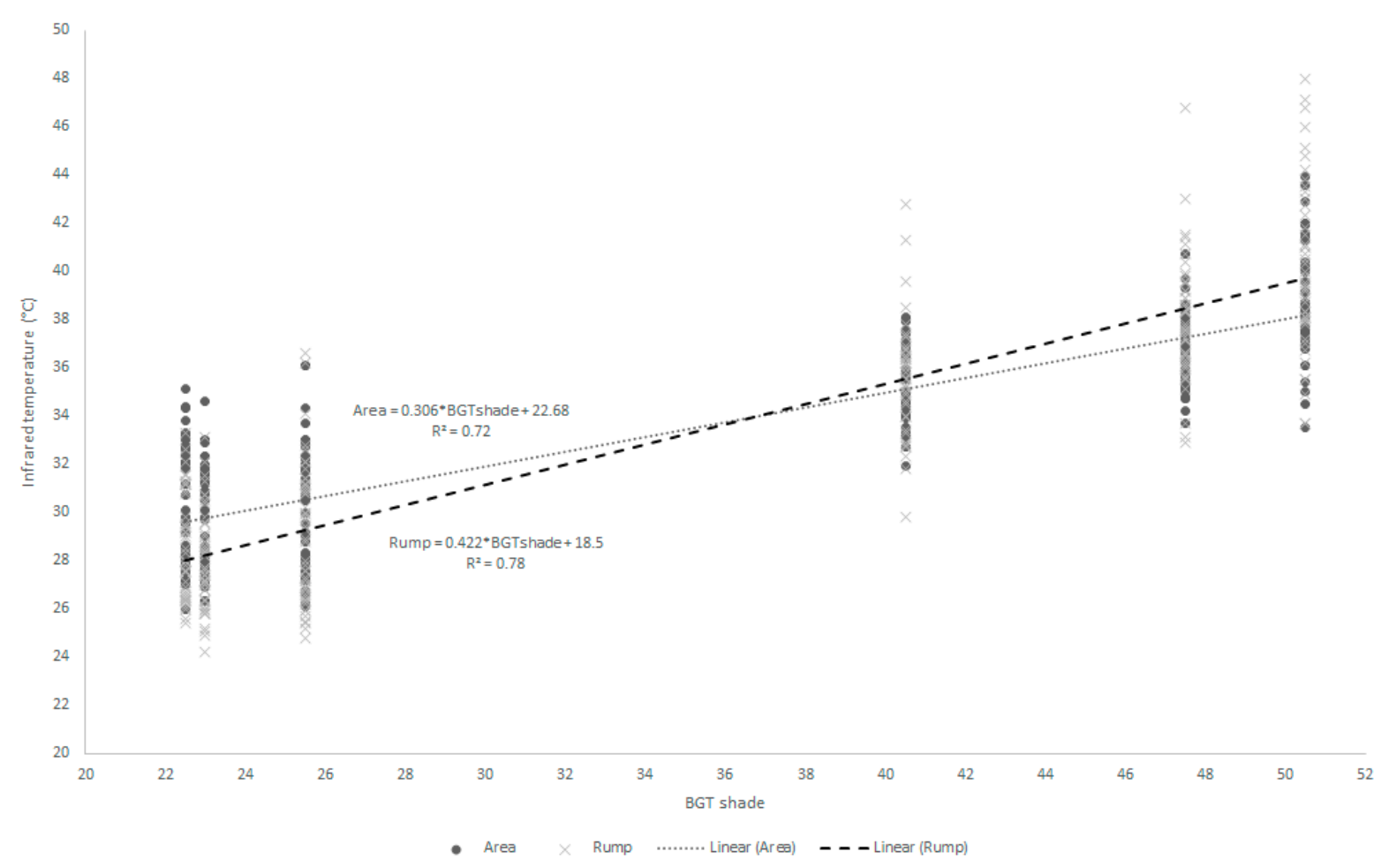

Figure 1. Data distribution and regression equation between infrared temperatures points (rump and flank) and black globe temperature under shade (BGTsd).

The first two factors (Figure 2) showed that, as air temperature increases, all thermographic measurements increased and Iberia and Baccari indices decreased along with RH. In the second moment, higher AT was associated with increasing RT, RR as well as nose temperatures but this was not accompanied by increasing measurements from the other thermograph measurements. This may indicate a limit to the animal's ability to lose heat from it surface area while continuing to produce heat internally. 


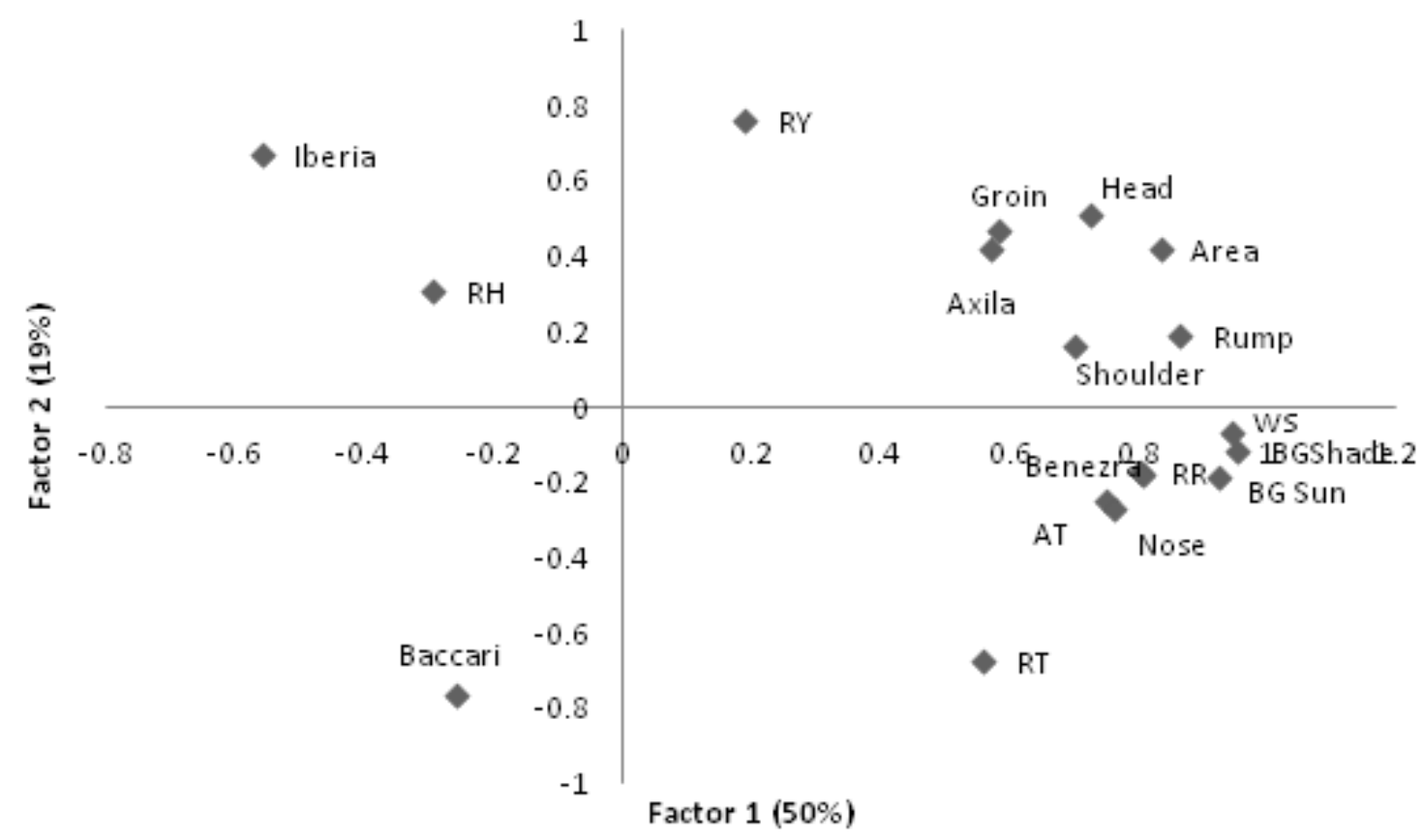

Figure 2. First two eigenvectors for climatic and thermograph measures on lambs. RR-respiratory rate; RT-rectal temperature; RY-Rauschenbach Yerokhin index; AT-air temperature; RH-relative humidity; WS-windspeed; BGTsun-Black Globe temperature in the sun and shade (BGTsd).

In the morning, the Iberia and Rauschenbach-Yerokhin tests, which used RT in the formula, were in different components than Benezra which also used RR (Figure 3). In the afternoon, the Baccari index passed to the second factor; that is, increasing RT decreased the Baccari index score indicating lower adaptation of the animal. In the afternoon, RT was close to zero and RR maintained its location, alongside Benezra (Figure 3).

The first two factors for analysis of tolerance traits measured with thermography and carcass traits explained $85 \%$ of the variation. Increasing infrared thermography values is accompanied by reduced weight of carcass traits such as weight of the loin, belly, ham and shoulder diameter, and may infer that animals with high surface body temperature have lighter carcasses.

When studying morphology with physiological traits, the first two factors explained $84 \%$ of the total variation between the characteristics in the afternoon. The first component separated the size and carcass traits, with little effect on physiological measures. The second component shows that animals with higher values of HR, RT and RR had shorter legs and lighter shoulder cuts.

The discriminant analysis demonstrated the percentage of animals that were correctly classified within each group according to tolerance to heat and physiological parameters such as RT, RR and HR. Generally, in the morning, the animals were not under heat stress (not shown) so comparisons here do not tell us much about the tolerance of these groups. In the afternoon, PRSI scored 100\% correct classification using heat tolerance tests and physiological parameters (Table 7). This was the group that showed greater adaptability to tropical climatic conditions in this study. The afternoon increased the impact of infrared temperatures and physiological mechanisms that the animals may have used for maintenance of homeothermy, as the animals were under greater stress in this period. 


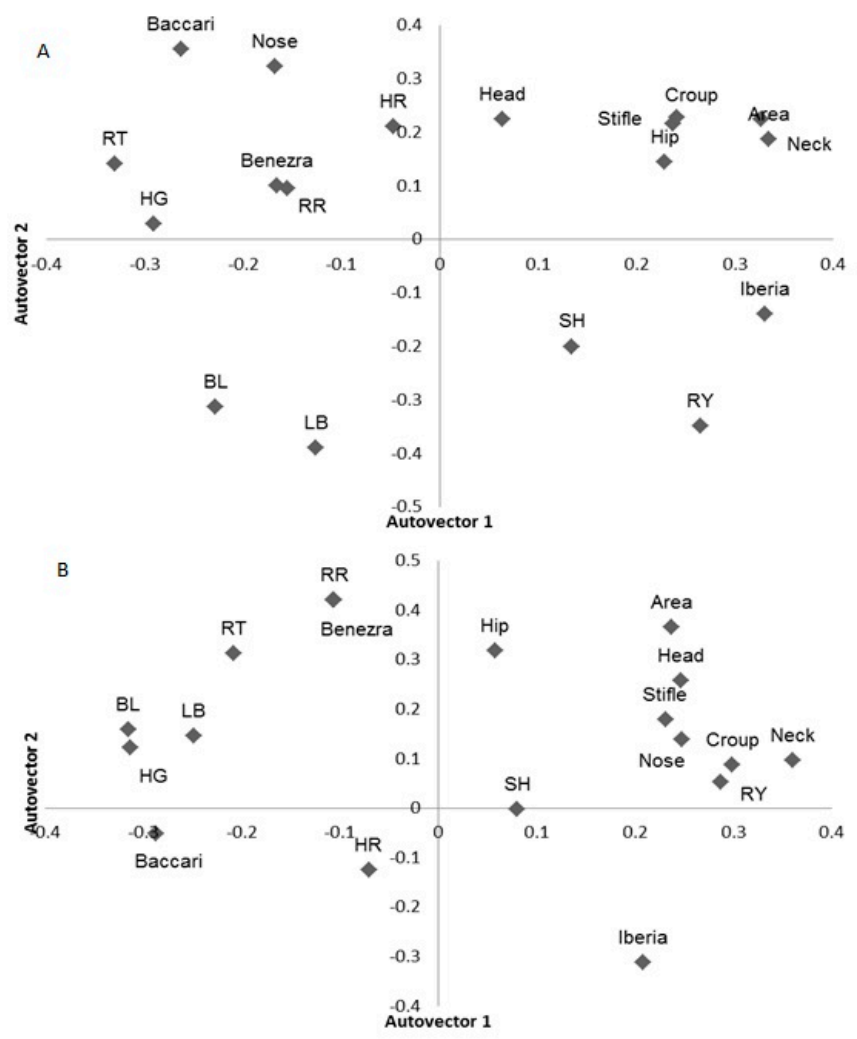

Figure 3. First two principal components for adaptability tests, physiological variables and infrared temperatures in lambs during the morning (A) and afternoon (B). BL: Body Length (cm); LB: Length of Back (cm); HG: heart girth (cm); SH: Shoulder Height $(\mathrm{cm})$; Flank, Head, Nose, Neck, Stifle and croup: thermography temperatures $\left({ }^{\circ} \mathrm{C}\right)$, HR: heart rate (beats/min); RR: respiratory rate ( $\mathrm{mov} / \mathrm{min})$; RT: rectal temperature $\left({ }^{\circ} \mathrm{C}\right)$, Iberia: Iberia test; Benezra: Benezra test; RY: Rauschenbach-Yerokhin test; Baccari: Baccari Jr. test.

Table 7. Percentage of observations correctly identified (bold numbers) within their genetic group by discriminant analysis for heat tolerance tests and physiological parameters measured on lambs in the afternoon.

\begin{tabular}{ccccccccc}
\hline & EFSI & PRSI & 87PDSI & SI & DOPD & PDSI & WDPD & 75PDSI \\
\hline EFSI & $\mathbf{8 0}$ & 20 & 0 & 0 & 0 & 0 & 0 & 0 \\
PRSI & 0 & $\mathbf{1 0 0}$ & 0 & 0 & 0 & 0 & 0 & 0 \\
87PDSI & 25 & 0 & $\mathbf{5 0}$ & 0 & 0 & 25 & 0 & 0 \\
SI & 20 & 0 & 0 & $\mathbf{6 0}$ & 0 & 0 & 20 & 0 \\
DOPD & 0 & 0 & 16.67 & 16.67 & $\mathbf{6 6 . 6 7}$ & 0 & 0 & 0 \\
PDSI & 0 & 0 & 0 & 0 & 16.67 & $\mathbf{6 6 . 6 7}$ & 0 & 16.67 \\
WDPD & 0 & 0 & 16.67 & 16.67 & 16.67 & 0 & $\mathbf{1 6 . 6 7}$ & 33.33 \\
75PDSI & 0 & 33.33 & 0 & 0 & 0 & 16.67 & 16.67 & $\mathbf{3 3 . 3 3}$ \\
\hline
\end{tabular}

PD: Poll Dorset; PR: Primera; EF: East Friesian; SI:Santa Inês; WD: White Dorper; DO: Dorper.

Heart rate was an important discriminating trait, especially for PD crosses. Note that the most frequent type of index used in separating groups of sheep was the Rauschenbach-Yerokhin, developed especially for sheep (Table 8) [13]. The Iberia test, which uses RT, was also important in separating several genetic groups. On the other hand, the Baccari test was important in discriminating the 75PDSI 
group. This represents the difference between morning and afternoon temperatures for which this group had an intermediate level.

Table 8. Physiological parameters and heat tolerance indices responsible for differentiation between eight genetic groups of lambs.

\begin{tabular}{|c|c|c|c|c|c|c|c|}
\hline & PRSI & 87PDSI & SI & DOPD & PDSI & WDPD & 75PDSI \\
\hline EFSI & Benezra RY & Baccari Iberia & RY HR & Iberia & HR & HR RT & Baccari HR \\
\hline PRSI & & Iberia & RY & Iberia RY & HR RT RY & Iberia HR RY & Baccari Iberia HR \\
\hline 87PDSI & & & RY Iberia & RY & HR & HR & Baccari RY HR \\
\hline SI & & & & Iberia RR & HR RT & HR RT & Baccari RY HR RT \\
\hline DOPD & & & & & HR Iberia RR RY & HR & Iberia RR HR \\
\hline PDSI & & & & & & HR & HR \\
\hline WDPD & & & & & & & Baccari RY HR \\
\hline
\end{tabular}

PD: Poll Dorset; PR: Primera; EF: East Friesian; SI:Santa Inês; WD: White Dorper; DO: Dorper.

When only physiological and thermograph traits were examined (Table 9), most thermograph measures differed between genetic groups showing differing emissions of heat. Rump temperature and RT were the variables that most appeared in genotype separations (Table 9).

Table 9. Differentiation between eight genetic groups of lambs using infrared thermography and physiological parameters.

\begin{tabular}{|c|c|c|c|c|c|c|c|}
\hline & PRSI & 87PDSI & SI & DOPD & PDSI & WDPD & 75PDSI \\
\hline EFSI & $\begin{array}{c}\text { RT } \\
\text { Rump } \\
\text { Head }\end{array}$ & $\begin{array}{c}\text { RT Armpit } \\
\text { Rump Neck } \\
\text { Head }\end{array}$ & Head HR RR & RT Stifle Nose & RR Rump Nose & RT Stifle Rump Nose Neck & Rump Head \\
\hline PRSI & & RT Head & $\begin{array}{l}\text { RT Rump } \\
\text { Neck }\end{array}$ & RT Rump & RT & RT Stifle Head & RT Stifle \\
\hline 87PDSI & & & $\begin{array}{l}\text { Neck Stifle } \\
\text { Flank Head }\end{array}$ & $\begin{array}{c}\text { RT Armpit Rump } \\
\text { Stifle Flank }\end{array}$ & $\begin{array}{l}\text { RT RR Rump } \\
\text { Armpit Stifle }\end{array}$ & RR Flank Croup & Armpit \\
\hline SI & & & & RT Flank & RR Rump Nose & $\begin{array}{c}\text { RR RT HR Rump Stifle } \\
\text { Flank Neck }\end{array}$ & Rump Neck Head \\
\hline DOPD & & & & & RT Flank Head & RT Flank & $\begin{array}{c}\text { RT HR Rump Head } \\
\text { Neck }\end{array}$ \\
\hline 75PDSI & & & & & & RT Stifle & Head Nose \\
\hline WDPD & & & & & & & RR Stifle \\
\hline
\end{tabular}

PD: Poll Dorset; PR: Primera; EF: East Friesian; SI:Santa Inês; WD: White Dorper; DO: Dorper.

The cluster analysis, in the morning, indicated that the SI, PDSI and 75PDSI genetic groups were closely related in terms of response to the environment. All groups contained PD or SI genotypes (Figure 4). The PRSI differentiate from other genetic groups in the morning and afternoon, which is probably related to results obtained in adaptability tests (RY and Ibéria), infrared temperature and rectal temperature in the afternoon, that demonstrate a better adaptation of this group to heat stress. 

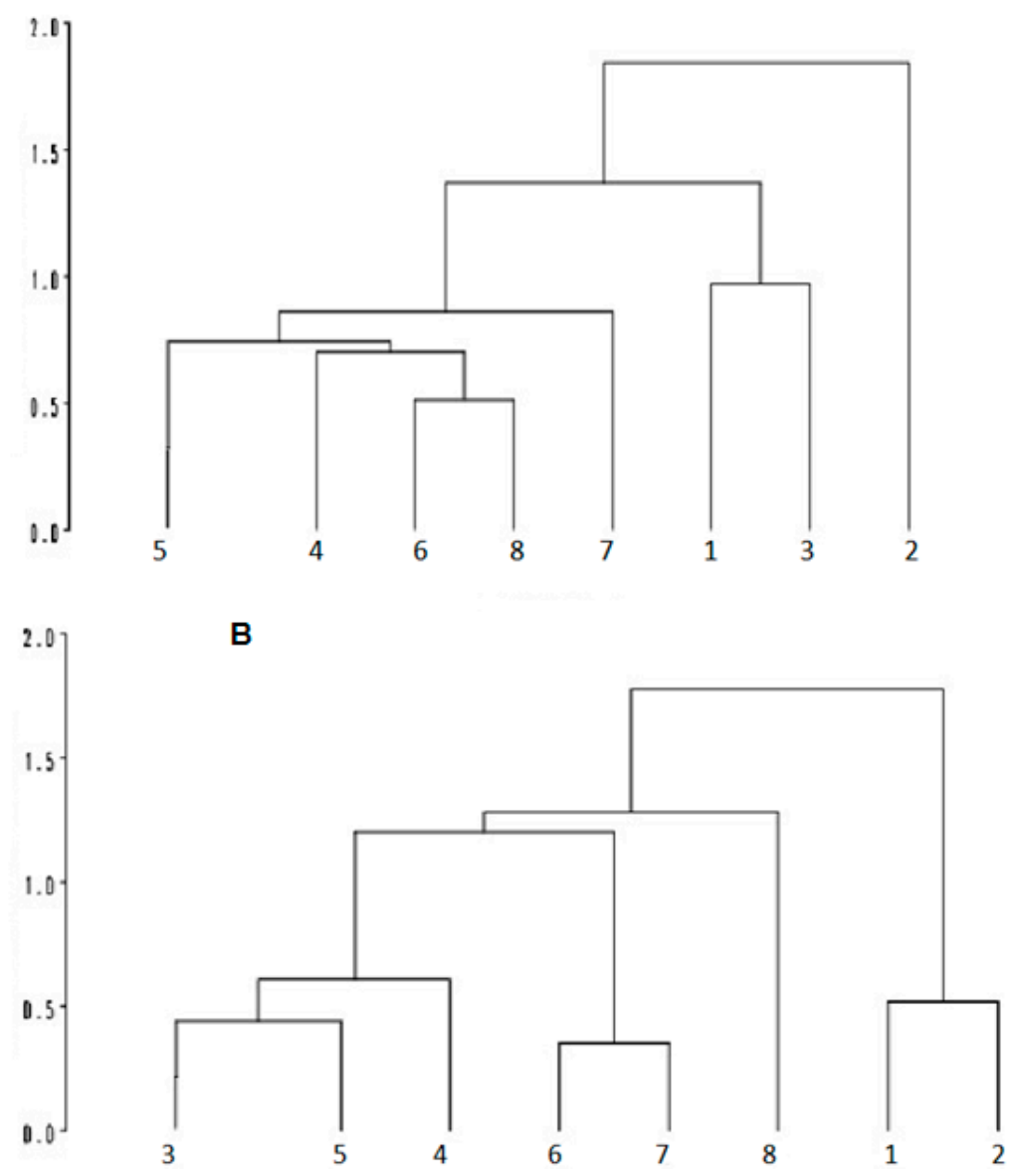

Figure 4. Cluster analysis of variables in the morning (A) and afternoon; (B) based on thermograph and physiological measures in lambs during the morning (A) and afternoon; (B) 1: EFSI; 2: PRSI; 3: 87PDSI; 4: SI; 5: DOPD; 6: PDSI; 7: WDPD; 8: 75PDSI.

\section{Discussion}

Animals in stressful environmental conditions use physiological mechanisms to return to homeothermy. If they fail to regain adequate body temperature, they begin to change their behavior, such as reducing food intake, showing a drop in productivity. According to Cunningham [16], changes in physiological parameters are evidence of attempts to move out of the heat stress condition to which the animals have been submitted.

During the afternoon, approximately $52 \%$ animals were classified as suffering from high stress, showing that many animals were able to use physiological mechanisms to maintain homeothermy. RR increase was also noted in the afternoon by Brasil et al. [17], in goats, and McManus et al. [18], in sheep, and RR is commonly used as a measure of heat stress [19]. When air temperature increases, thermoregulatory mechanisms enter in action increasing heat loss through increased sweating and RR [20]. In sheep, the respiratory tract is a primary mechanism for heat dissipation [21] and several studies have demonstrated that this physiological parameter a good indicator of heat stress. McManus et al. [18] concluded that the increase in respiratory rate can be considered the primary control mechanism under the environmental conditions imposed, accompanied by other mechanisms, such as increased sweating rate. 
Rectal temperature is also a parameter widely used to determine the degree of adaptability of the animals, since an increase of this variable for the species indicates that the animal is storing heat, and so thermal stress may manifest itself [22]. Normal rectal temperatures in sheep vary from 38.5 to $39.9{ }^{\circ} \mathrm{C}$ [16]. Some genetic groups showed RT above the reference value indicating difficulty in maintaining homeothermy [21]. Generally, an increase in $1{ }^{\circ} \mathrm{C}$ in rectal temperature is enough to reduce performance in most domestic species [23]. The PRSI genetic group had the highest percentage of animals with RT below $39.9^{\circ} \mathrm{C}(91.18 \%)$, indicating that these animals probably suffered less from heat stress.

Rectal temperature in sheep starts to increase when environmental temperature rises above $32{ }^{\circ} \mathrm{C}$ [16]. PRSI had the lowest RT $\left(39.43{ }^{\circ} \mathrm{C}\right)$ in the afternoon. These animals may have used respiratory evaporation and peripheral vasodilation to lose enough heat to maintain their body temperature. On the other hand, the EFSI group showed high HR and RR demonstrating low adaptation and, at the same time, had higher thermography temperatures. Probably, EFSI animals had greater increase in blood flow to the body surface to maintain homeothermy, causing an increase in surface temperature [24].

The cluster analysis showing the distance between genetic groups also demonstrated these relationships. The PRSI group differed from others in the morning and the PRSI and EFSI differed from others in the afternoon. In the morning, PRSI seems to be the best-adapted group with low physiological parameters (RT, HR, RR) and infrared temperatures. In the afternoon, the PRSI and EFSI increased their surface temperature to lose heat to maintain their body temperature, as these two groups did not show high RT in the afternoon.

The DOPD had the highest percentage of animals with RT above $39.9^{\circ} \mathrm{C}(52.78 \%)$. Moreover, this group had the highest MCHC corroborating with the inferences that this genetic group suffers with high air temperatures and solar radiation. Long term heat stress can reduce the number of red blood cells [25], directly influencing MCV, MCH and MCHC. Therefore, the DOPD seems be group with the poorest adaptation in this study.

In the Rauschenbach-Yerokhin test, the animals failed to exceed $73.28 \%$ efficiency in maintaining homeothermy. Note that air temperature is used for this calculation. The Santa Inês group demonstrated heat intolerance to this (54.48) and the adapted Baccari Jr. (8.32) tests, differing from other genetic groups. The Santa Ines is a Brazilian locally adapted hair breed, which is expected to be well adapted to climatic conditions. However, aiming to improve production traits, the breed recently underwent an introgression process through crossing strategies with specialized meat breeds [8]. This may have promoted losses in adaptation traits [10].

The fact that the pure Santa Ines or crossbred Dorper groups do not distance themselves from the others, especially when a breed that is, supposedly, not heat tolerant is used, makes it clear that the sale of these animals as a well heat-adapted breed is a marketing strategy that farmers should be aware of $[2,10,26]$. Moreover, further studies should be conducted with these groups since genetic selection for increases in productivity may decrease rusticity and adaptability.

Castanheira et al. [27] used multivariate analysis to discriminate genetic groups of sheep, based on physiological and physical characteristics of heat tolerance. Other authors have used multivariate analyses to analyze the distance between genetic groups based on morphological characteristics in sheep and goats, including Herrera et al. [28], Dossa et al. [29] and Traore et al. [30]. As in these, in 
the present study, size traits were seen to be important in discriminating between genetic groups, as were physiological parameters.

Correlations between thermography, environmental and physiological measures were medium to high and predictive equations show that this method should be efficient in determining respiration rate and rectal temperature in lambs, thereby avoiding unnecessary handling and stress for these animals. The thermography temperatures, mainly flank and rump (high coefficient of determination), yield significant regression with black globe temperature under shade, demonstrating the relation between the thermography and environmental data.

Thermography was shown to be efficient in measuring heat stress in lambs, with medium-high correlations between these measurements and traditional heat tolerance measures such as RR and RT. This has the advantage that it is a non-invasive technique [31,32]. Montanholi et al. [33] also found that infrared thermography can be successfully applied for assessing heat and methane production in cattle in an experimental chamber. Their correlations with heat production were in line with those found here for rectal temperatures.

The use of thermal images is a non-invasive technique, which may avoid some of these stress problems involved with estimating heat tolerance in animals without causing interaction though handling. As seen here, it can successfully discriminate between genetic groups and are related to physiological measurements in the animals. These measurements were also seen to be related to red blood series parameters, which are widely used to assess the ability of breeds to adapt, since they are directly involved in mechanisms of heat loss [22].

The main regions of the animal body to measure using thermography seem to be the flank, nose and rump, which is in agreement with results found by Paim et al. [13]. Therefore, these points of animal body should be used in further studies using infrared to confirm their usefulness in heat tolerance assessment in lambs.

In recent years, climate change has led to an increase in the number of studies looking at animal welfare, in an attempt to minimize economic losses resulting from the adverse effects of climate on animal production in the tropics $[4,13,26]$. In this context, new technologies such as thermography could be included to facilitate measurement of stress in animals.

\section{Conclusions}

The assessment of body surface temperature measured by the thermograph is an alternative non-invasive tool for measuring the heat produced and tolerance in lambs. Genetic group is an important factor in heat tolerance and should be taken into consideration when introducing new breeds into production systems. Rectal temperature, heart rate, and thermographic temperature at the rump, flank and nose are important variables for heat tolerance assessment in lambs.

\section{Acknowledgments}

Thanks are due to students at the Universidade Federal de Goiás for help in carrying out the experiment. FAPDF project number 193.000.287/07; INCT-Pecuária, CNPq (474330/2010-9) and CAPES are acknowledged for scholarships. 


\section{Author Contributions}

Concepta McManus, Eliandra Bianchini and Tiago do Prado Paim conceived and designed the experiments; Eliandra Bianchini, Flavia Gontijo de Lima , Marlos Castanheira, Geisa Isilda Ferreira Esteves, Caio Cesar Cardoso and Vanessa Calderaro Dalcin performed the experiments; Concepta McManus and José Braccini Neto analyzed the data; Eliandra Bianchini and Tiago do Prado Paim wrote the paper; Concepta McManus and José Braccini Neto revised the paper.

\section{Conflicts of Interest}

The authors declare no conflict of interest.

\section{References}

1. Starling, J.M.C.; de Silva, R.G.; Cerón-Muñoz, M.; Barbosa, G.S.S.C.; de Costa, M.J.R.P. Análise de algumas variáveis fisiológicas para avaliação do grau de adaptação de ovinos submetidos ao estresse por calor. Revista Brasileira de Zootecnia 2002, 31, 2070-2077. (In Portuguese)

2. McManus, C.; Paiva, S.R.; de Araújo, R.O. Genetics and breeding of sheep in Brazil. Revista Brasileira de Zootecnia 2010, 39, 236-246. (In Portuguese)

3. De Lima, C.C.V.; Silva, D.; Costa, J.N.; Costa Neto, O.A.; de Souza, T.S. Parâmetros fisiológicos de cordeiros mestiços (1/2 e 3/4 dorper) do nascimento até os 90 dias de idade. Revista Brasileira de Saúde e Produção Animal 2010, 11, 354-361. (In Portuguese)

4. Souza, B.; Lopes, J.; Roberto, J.; Silva, M.; Silva, E.; Silva, G. Efeito do ambiente sobre os parâmetros fisiológicos de caprinos Saanen e mestiços $1 / 2$ Saanen $+1 / 2$ Boer no semi-árido paraibano. Agropecuária Científica no Semi-Árido 2010, 6, 47-51. (In Portuguese)

5. Ferreira, R.A.; Estrada, L.H.C.; Thiébaut, J.T.L.; Granados, L.B.C.; de Souza Júnior, V.R. Avaliação do comportamento de ovinos santa inês em sistema silvipastoril no norte fluminense. Ciência e Agrotecnologia 2011, 35, 399-403. (In Portuguese)

6. Loarie, S.R.; Duffy, P.B.; Hamilton, H.; Asner, G.P.; Field, C.B.; Ackerly, D.D. The velocity of climate change. Nature 2009, 462, 1052-1055.

7. Tubiello, F.N.; Soussana, J.F.; Howden, S.M. Crop and pasture response to climate change. Proc. Natl. Acad. Sci. USA 2007, 104, 19686-19690.

8. McManus, C.; Louvandini, H.; Paim, T.D.P.; Martins, R.S.; Barcellos, J.O.J.; Cardoso, C.; Guimarães, R.F.; Santana, O.A. The challenge of sheep farming in the tropics: Aspects related to heat tolerance. Revista Brasileira de Zootecnia 2011, 40, 107-120.

9. De Sousa Júnior, S.C.; Morais, D.A.E.F.; de Vasconcelos, Â.M.; Nery, K.M.; Morais, J.H.G.; Guilhermino, M.M. Características termorreguladoras de caprinos, ovinos e bovinos em diferentes épocas do ano em região semi-árida. Revista Científica de Produção Animal 2008, 10, 127-137. (In Portuguese)

10. Ferreira, R.A. Maior Produção com Melhor Ambiente Para Aves, Suínos e Bovinos; Aprenda Fácil: Viçosa, Brasil, 2005. (In Portuguese)

11. Reece, W.O. Functional Anatomy and Physiology of Domestic Animals; John Wiley \& Sons: Ames, IA, USA, 2009. 
12. Baccari Júnior, F. Métodos e técnicas de avaliação da adaptabilidade dos animais nos trópicos. Semana de Zootecnia 1986, 11, 53-64. (In Portuguese)

13. Paim, T.P.; Borges, B.O.; Lima, P.D.M.T.; Gomes, E.F.; Dallago, B.S.L.; Fadel, R.; de Menezes, A.M.; Louvandini, H.; Canozzi, M.E.A.; Barcellos, J.O.J. Thermographic evaluation of climatic conditions on lambs from different genetic groups. Int. J. Biometeorol. 2013, 57, 59-66.

14. Silva Sobrinho, A.G. Criação de ovinos. Jaboticabal: Funep 2001, 3, 320. (In Portuguese)

15. Silanikove, N. Effects of heat stress on the welfare of extensively managed domestic ruminants. Livest. Prod. Sci.2000, 67, 1-18.

16. Cunningham, J. Cunningham's Textbook of Veterinary Physiology; Elsevier: New York, NY, USA, 2011.

17. Brasil, L.H.D.A.; Wechesler, F.S.; Baccari Júnior, F.; Gonçalves, H.C.; Bonassi, I.A. Efeitos do estresse térmico sobre a produção, composição química do leite e respostas termorreguladoras de cabras da raça alpina. Revista Brasileira de Zootecnia 2000, 29, 1632-1641. (In Portuguese)

18. McManus, C.; Paludo, G.R.; Louvandini, H.; Gugel, R.; Sasaki, L.C.B.; Paiva, S.R. Heat tolerance in brazilian sheep: Physiological and blood parameters. Trop. Anim. Health Prod. 2009, 41, 95-101.

19. Dos Santos, F.C.B.; de Souza, B.B.; Alfaro, C.E.P.; Cézar, M.F.; Filho, E.C.P.; Acosta, A.A.A.; dos Santos, J.R.S. Adaptabilidade de caprinos exóticos e naturalizados ao clima semi-árido do nordeste brasileiro. Ciênc. Agrotec. 2005, 29, doi:10.1590/S1413-70542005000100018. (In Portuguese)

20. Oliveira, F.M.; Dantas, R.T.; Furtado, D.A.; de Nascimento, J.; Medeiros, A.N. Parâmetros de conforto térmico e fisiológico de ovinos santa inês, sob diferentes sistemas de acondicionamento. Revista Brasileira de Engenharia Agrícola e Ambiental 2005, 9, 631-635. (In Portuguese)

21. Marai, I.; El-Darawany, A.; Fadiel, A.; Abdel-Hafez, M. Physiological traits as affected by heat stress in sheep-A review. Small Rumin. Res. 2007, 71, 1-12.

22. Da Siva, E.M.N.; de Souza, B.B.; de Sousa, O.B.; de Assis Silva, G.; de Freitas, M.M.S. Avaliação da adaptabilidade de caprinos ao semiárido através de parâmetros físiológicos e estruturas do tegumento. Revista Caatinga 2010, 23, 142-148. (In Portuguese)

23. McDowell, R.E. Improvement of livestock production in warm climates. Improv. Livest. Prod. Warm Clim. 1972, 1, 711.

24. Ribeiro, N.L.; Furtado, D.A.; Medeiros, A.N.; Ribeiro, M.N.; Silva, R.C.; Souza, C.M. Avaliação dos índices de conforto térmico, parâmetros fisiológicos e gradiente térmico de ovinos nativos. Engenharia Agrícola 2008, 28, 614-623. (In Portuguese)

25. Bezerra, W.M.D.A.X.; de Souza, B.B.; de Sousa, W.H.; Cunha, M.D.G.G.; Benicio, T.M.A. Comportamento fisiológico de diferentes grupos genéticos de ovinos criados no semiárido paraibano. Revista Caatinga 2010, 24, 130-136. (In Portuguese)

26. Paim, T.; Borges, B.; Lima, P.; Dallago, B.; Louvandini, H.; McManus, C. Relation between thermographic temperatures of lambs and thermal comfort indices. Int. J. Appl. Anim. Sci 2012, 1, 108-115.

27. Castanheira, M.; Paiva, S.R.; Louvandini, H.; Landim, A.; Fiorvanti, M.C.; Dallago, B.S.; Correa, P.S.; McManus, C. Use of heat tolerance traits in discriminating between groups of sheep in central brazil. Trop Anim. Health Prod. 2010, 42, 1821-1828. 
28. Herrera, M.; Rodero, E.; Gutierrez, M.; Pena, F.; Rodero, J. Application of multifactorial discriminant analysis in the morphostructural differentiation of andalusian caprine breeds. Small Rumin. Res. 1996, 22, 39-47.

29. Dossa, L.H.; Wollny, C.; Gauly, M. Spatial variation in goat populations from benin as revealed by multivariate analysis of morphological traits. Small Rumin. Res. 2007, 73, 150-159.

30. Traoré, A.; Tamboura, H.H.; Kaboré, A.; Royo, L.; Fernández, I.; Álvarez, I.; Sangaré, M.; Bouchel, D.; Poivey, J.; Francois, D. Multivariate characterization of morphological traits in burkina faso sheep. Small Rumin. Res. 2008, 80, 62-67.

31. Bergman, T.L.; Lavine, A.S.; Incropera, F.P.; DeWitt, D.P. Fundamentals of Heat and Mass Transfer; John Wiley \& Sons: Hoboken, NJ, USA, 2011.

32. Bouzida, N.; Bendada, A.; Maldague, X.P. Visualization of body thermoregulation by infrared imaging. J. Therm. Biol. 2009, 34, 120-126.

33. Montanholi, Y.R.; Odongo, N.E.; Swanson, K.C.; Schenkel, F.S.; McBride, B.W.; Miller, S.P. Application of infrared thermography as an indicator of heat and methane production and its use in the study of skin temperature in response to physiological events in dairy cattle (bos taurus). J. Therm. Biol. 2008, 33, 468-475.

(C) 2015 by the authors; licensee MDPI, Basel, Switzerland. This article is an open access article distributed under the terms and conditions of the Creative Commons Attribution license (http://creativecommons.org/licenses/by/4.0/). 